\title{
NOTA BIBLIOGRÁFICA: IMAGEN DE DIOS. ANTROPOLOGÍA TEOLÓGICA FUNDAMENTAL
}

\section{BIBLIOGRAFICAL NOTE: IMAGE OF GOD. FUNDAMENTAL THEOLOGICAL ANTROPOLOGY}

\author{
MARIANO RUIZ ESPEJO \\ Universidad Católica San Antonio de Murcia
}

Recibido: 01/03/2019 Aceptado: 24/04/2019

\section{RESUMEN}

En este trabajo se sintetiza y comenta la sexta edición del libro de título como indica el encabezamiento del presente artículo. El libro es de indudable calidad sobre el tema antropológico para un público creyente e iniciado en teología porque da un enfoque cristiano y católico en contraste con otras percepciones de la cuestión a lo largo de la historia hasta la fecha de publicación. En concreto, presentamos un resumen de la revelación bíblica sobre la antropología tanto del Antiguo (teocéntrica) como del Nuevo Testamento (cristocéntrica) siguiendo al autor del libro. El resto de su contenido es comentado de acuerdo al estudio sistemático que realiza el autor sobre el hombre como ser unitario (alma-cuerpo), como ser personal (y su dignidad), como ser creativo (y su actividad en el mundo), y como ser creado (y su origen). Tras una revisión de su contenido, hemos comentado algunos aspectos de interés personal como son el objetivo del autor del libro, lo que aporta sobre la fe, su originalidad en el contexto bíblico y eclesial además de otras perspectivas relacionadas, posiciones difíciles de entender, su interés pastoral y pedagógico, y finalmente planteamos alguna cuestión que surge leyendo el texto.

Palabras clave: antropología; Biblia; hombre; teología. 


\section{ABSTRACT}

In this work we sinthetize and comment the sixth edition of the book of title as it is indicated in heading of this article. The book has an undoubtable quality about the anthropologic theme for a believer public and initiated in theology because it gives a Christian and Catholic focus in contrasting with other perceptions of the question along the history until the date of publication. Concretely, we present a summary of biblical revelation on anthropology from both Ancient (theocentric) and New Testament (Christcentric) following the author of the book. Rest of its content is commented according to systematic study realized by author about the man as unitary being (soul-body), as personal being (and his dignity), as creative being (and his activity in the world), and as created being (and his origin). After a revision of its content, we have commented some aspects of personal interest as they are the objective of author of book, what it apports over the faith, its originality in the biblical and ecclesial context moreover of other related perspectives, difficult positions of understanding, its pastoral and pedagogic interest, and finally we raise some question which arises reading the text.

Keywords: anthropology; Bible; man; theology.

El autor de este libro es un sacerdote y teólogo español de los dos últimos tercios del siglo XX, profesor de distintas universidades y autor de un número apreciable de libros sobre su especialidad de Antropología Teológica y Escatología, llegando a ser catedrático por la Universidad Pontificia de Salamanca.

El libro puede considerarse una monografía científica muy documentada pues hace referencia a muchos autores y sus obras sobre los temas que van apareciendo en las páginas del mismo y, por lo general, para hacer indicaciones muy oportunas sobre los contenidos desarrollados y explicados, con una intención general expositiva personal y a veces exegética, así como explicativa con perspectiva histórica de los diversos autores que han tratado los aspectos relativos a su exposición y sus aportaciones respectivas ya sea de filósofos, científicos, autores cristianos, documentos del magisterio de la Iglesia, Sagrada Escritura, etc.

El contenido se divide en dos partes. La primera de "Antropología Bíblica", que consta de dos capítulos, el primero referido al Antiguo Testamento (imagen de Dios), el segundo referido al Nuevo testamento (en Cristo). La segunda parte de "Antropología Sistemática" contiene cuatro capítulos, el tercero dedicado al hombre como ser unitario (alma-cuerpo), el cuarto dedicado al hombre como ser personal (dignidad de la imagen), el quinto dedicado al hombre como ser creativo (actividad humana en el mundo) y el sexto dedicado al hombre como ser creado (cuestión del origen). 
Centrándonos en el capítulo primero, el autor distingue tres términos hebreos clave para descifrar la antropología del Antiguo Testamento (AT): basar (carne del ser vivo, solidaridad), nefes (garganta, órgano de la respiración), ruah (brisa, viento, vitalidad, espíritu de Yahvé). Los dos primeros se usan indistintamente, el hombre está consagrado a la caducidad y abierto solo en sentido finito y horizontal. El tercero está verticalmente abierto a Dios, al carisma sobrenatural que participa del don divino salvífico. El AT narra el origen del mal, el drama de la caída del hombre y de la capacidad de afirmarse autónomamente ante Dios. El hagiógrafo se mueve por una finalidad religiosa, no científica o no profana. El hombre está en manos de Dios como el barro en manos del alfarero, y en su acogimiento de esta dependencia le va la vida al hombre. Trabajar la tierra y disfrutarla son cosas complementarias, hasta que el pecado perturbe el orden inicial. La relación del hombre con el mundo es de cuidado y de superioridad jerárquica, Dios es el único señor legítimo del mundo y no el hombre. Solamente en comunión con Dios hay vida estable ya que Dios es fuente de vida. Dios hace libre y responsable al hombre, se dirige a él, le habla y espera respuesta. Es un Dios padre, dador de vida, aliado y amigo del hombre; y el hombre precisa de un interlocutor inmanente, la mujer semejante a él como puro regalo divino sin herida ni sensación de vacío. La apertura del costado de Cristo reproduce y descifra la primera apertura del costado de Adán. Del costado de Cristo surgió la nueva humanidad nacida del agua y de la sangre (bautismo y eucaristía), del costado de Adán surgió la madre de la humanidad. De modo que la recta forma de autoafirmación del yo del hombre es afirmar al tú de su semejante. La mujer es sacada del varón y éste de la tierra, estando completo en la comunidad interpersonal, no en el aislamiento existencial. El AT subraya la unidad psicosomática del hombre completo como imagen de Dios. La humanidad pecadora postdiluviana también es imagen de Dios. El hombre como imagen de Dios lo representa en el mundo como su alter ego con potestad regia sobre los seres creados, que los preside y gobierna en nombre de Dios creador y por su delegación. El tercer hijo de Adán, Set, es imagen de Adán. Solo a Dios debe el hombre sumisión, y el resto de criaturas le están sometidas a él por voluntad divina. El dominio regio que compete al hombre es por ser criatura coronada de gloria y esplendor. Por ser imagen de Dios, el hombre es una magnitud inviolable y todo atentado contra el hombre será vindicado por Dios. Por ser rey y vicario el señorío humano sobre la creación implica la tutela de lo enseñoreado. Por la tendencia a identificar a la imagen con lo representado se prohibieron las imágenes en Israel y, también en el Islam hoy. La analogía entre Dios y el hombre se basa en su capacidad de la relación yo-tú. El hombre es para el hombre lo que Dios es para él, un tú. El hombre es un ser relacional con Dios y esta relación no le degrada sino que constituye la base de su dignidad; solo depende de Dios, de 
nadie más, y esa dependencia de relación recíproca le libera. El hombre está en la intersección del creador y de la creación. La fe en Yahvé ha visto al hombre teomorfo, no a Dios antropomorfo: el hombre es creado a imagen de Dios, los demás seres vivos según su especie. El ser humano tiene relación al tú, en la bipolaridad sexual de varón y mujer ordenada a la procreación y mutua complementariedad, y en su socialidad en la comunidad humana para ejecutar el encargo divino de llenar y someter la tierra con la bendición divina para ser fecundos. Como criatura de Dios el hombre depende del creador, como el barro del alfarero $(\mathrm{J})$ o como la imagen depende de lo imaginado $(\mathrm{P})$; aquí $\mathrm{J}$ se refiere al texto yahvista y $\mathrm{P}$ al sacerdotal. El hombre, todos los seres humanos, es efecto directo de la acción divina y su don de la vida, y el misterio de la generación humana hunde sus raíces en el misterio del mundo, todos deben a Dios su existencia hasta los que le niegan. Adán es el culmen de la creación divina, las demás criaturas son para él como él es para Dios. El gobierno del hombre es en nombre de Dios, responsable ante el Señor de su gestión. La relación a Dios es de inferioridad y respecto al mundo es de superioridad; la relación de socialidad es de igualdad, sin borrar la singularidad pues cada uno llega a ser uno mismo en fusión con el otro. Mundanal, libre y responsable: el hombre se dirige a Dios como a un tú, de él solo espera respuesta y solo al hombre se le encomienda el cuidado del mundo. En una estructura dialógica yo-tú. Con la ecuación hombre-imagen de Dios nos hace una reflexión del hombre para qué. El punto de partida no es la ontología del ser sino la axiología para ser el ser supremo para el hombre y para Dios. Creó al hombre el Señor de la tierra, de una fuerza suya lo revistió, le impuso su temor sobre toda carne para que domine la creación con inteligencia y discernimiento. Creado para la relación amistosa con Dios y no puede atentar contra su prójimo como imágenes de Dios. Los términos claves del libro de la Sabiduría ( $\mathrm{Sb}$ ) son sôma, psyché, sárx, pneûma. La antropología del libro Sb sigue sustancialmente a la del resto del AT: carne animada o alma encarnada, pero no "cuerpo más alma" y aunque haya huellas de helenización diversos autores descartan un pretendido platonismo (no hay huella de la pretendida preexistencia e inmortalidad del alma sino todo lo contrario: el premio de las almas intachables es la incorruptibilidad del hombre, no solo del alma; la muerte no es descrita nunca en Sb como separación del alma y el cuerpo, definición clásica de la antropología dicotómica, sino que el morir del justo es como un "ser tomado" por Dios y que el poder de Dios puede rescatarlo para volverlo a la vida; el término muerte en $\mathrm{Sb}$ es solo aplicado al destino del impío, jamás al fin de la existencia terrena del justo). La antropología del AT es muy estable, comprende unitariamente al ser humano, y destaca el carácter decisivo del hombre y su destino teologal ante Dios. 
El capítulo segundo de dedica a la imagen de Dios en Cristo y a la antropología del Nuevo Testamento (NT). En él se muestra la artificiosa división académica entre antropología teológica fundamental y antropología teológica especial, pues en el AT la interpretación del hombre era teo-logía y en el NT el discurso antropológico es cristología y soteriología (vernos en Cristo y salvarnos por Él). En el AT el hombre es criatura de Dios, en su ser y en la continuidad de su ser, mediante la confianza del creyente en Dios según enseña Cristo, como una completa disponibilidad similar a la del siervo hacia su señor. Pero ahora el siervo es hijo y el señor es padre, por lo que es necesario hacernos como niños para entrar en el reino de los cielos. El AT nos dice que el hombre es oyente de la palabra, mientras que el NT nos enseña que serán dichosos los que "oyen la palabra de Dios y la guardan" (Lc 11,28), los que se alimentan "no solo de pan, sino de toda palabra que sale de la boca de Dios" (Mt 4,4). Por su relación con Dios y su palabra, el hombre es el valor supremo de la creación, el fin y no un medio, al que todo se subordina. La antropología hebrea indica que el hombre es una unidad psicosomática. En el NT se nos habla de una vida (psyché = nefes) unidad indivisible que se logra o se malogra según se acepte o rechace seguir a Jesús y de que la vida vale más que todos los restantes bienes. De aquí que es Cristo y su obra salvadora de lo que dispone el hombre para asegurar su vida. Jesús entrega su vida en favor de muchos, y quien toma el yugo de Jesús sobre sí encuentra el descanso para su vida. Psyché significa un hombre, una persona; y la nefes es una expresión hebrea que a veces evoca un pronombre personal. La perseverancia hasta el fin garantiza la salvación. Ambas expresiones significan "ser viviente unitario". El alma y el cuerpo son dos aspectos de la persona biológica, el alma interior necesita comer para vivir, y el cuerpo exterior que necesita cubrirse con el vestido. Jesús explica que no tenemos que temer a quien mata el cuerpo, pero no puede matar el alma, sino a "quien" puede llevar a perder a ambos (cuerpo y alma) a la gehenna, y éste es solo Dios. Con sôma se designa al hombre en su totalidad, que evoca el significado de basar. Para San Pablo el hombre es básicamente el hombre del AT. "Que todo vuestro ser, el espíritu (pneûma), el alma (psyché) y el cuerpo (sôma) se conserve sin mancha..." escribe San Pablo en 1 Ts 5,23. Similares expresiones aparecen en Dt 6,5 y Sal 16,9-10. La alternativa muerte o resurrección aparece taxativamente en 1 Co 15,29-32. La polivalencia del término ruah, usado a veces como nefes, y de pneûma en sentido análogo a psyché, y a veces se usa ruah como carisma o incluso a sarx como pronombre hebreo basar, vosotros. La carne no es mala, solo lo es cuando el hombre decide edificar su vida autónomamente sobre ella. La exégesis actual, con la excepción de Gundry, designa por sôma a la persona entera. Vuestros cuerpos son miembros de Cristo (1 Co 6,15), vosotros sois el cuerpo de Cristo (1 Co 12,27), nosotros... no formamos más que un solo cuerpo 
(Rm 12,5), corroboran la sinonimia cuerpo-pronombre personal; vuestro cuerpo es santuario del Espíritu Santo (1 Co 6,19; 3,16-17). Solo el alma, no el cuerpo, es la realidad puente entre la vida terrenal y la vida resucitada. Los exegetas difieren en sus respuestas a la pregunta de si por sôma puede ser designada la persona como un todo, pero parece imponerse la comprensión de que por sôma se entiende el sujeto consigo mismo, con los otros, con el ambiente y con Dios. Es idónea para significar la comunidad del cuerpo de Cristo. San Pablo hace de este término la clave de bóveda de su antropología, de la existencia del hombre indivisible y de su relación con Dios, llamado a transformarse en cuerpo espiritual anexionándose al cuerpo de Cristo que es la Iglesia y pasando de su finitud nativa carnal a la espiritual resultando una nueva creación. Cristo es imagen de Dios y el cristiano es imagen de Cristo y, como consecuencia, el cristiano es imagen de Dios. El hombre no tiene que cubrirse la cabeza porque es imagen y gloria de Dios. Era necesario un Adán verdadero, auténtica imagen de Dios, que es Cristo (2 Co 4,4), que irradia esplendor por su divinidad e imagen del Dios invisible. Desde este momento el NT nos indica que el sentido del hombre es ser imagen de Cristo, y el fulgor del rostro de sus discípulos es progresivo y permanente; Jesús transfigurará nuestro cuerpo en un cuerpo glorioso como el suyo (Flp 3,21). La relación del cristiano con Cristo es dinámica en su interrelación personal. La promesa del AT en la teología de la imagen se ha cumplido en Jesucristo: Dios ha querido ser como hombre en Cristo. La existencia humana queda realizada cuando se orienta hacia la consecución de la imagen de Dios, y esto es imposible al margen de Cristo. Al depender el hombre de Dios queda liberado de la servidumbre del mundo, Dios le da libertad verdadera y alegría y gozo. La concepción unitaria de la persona humana es característica de la antropología del NT, a diferencia de la comprensión dicotómica del hombre como compuesto de cuerpo y alma. Este dualismo es inviable ante la encarnación del Verbo y la resurrección de Jesús y de los muertos. El carácter corpóreo de la salvación es clave en mensaje paulino. Para la antropología cristiana ésta es función de la cristología. El hombre como unidad psicoorgánica es imagen de Dios y de valor absoluto. En la medida en que se entrega el hombre su suerte depende de Dios y alcanza su esencia, Dios le acompaña siempre hasta la consumación final como hombre entero. Tanto el AT como el NT conciben al hombre como unidad psicosomática y no conoce las nociones de alma y cuerpo como partes separadas o distintas. En el hombre paulino hay dualidad ontológica, pluralismo funcional y unidad hegemónica, según Gundry, cuya exégesis es cuestionable. Otro autor, el teólogo luterano Heidler, defiende que la inmortalidad del alma es doctrina bíblica. 
La segunda parte de Antropología Sistemática comienza con el capítulo tercero sobre el problema alma-cuerpo y el hombre, ser unitario. Anteriormente se ha considerado al hombre en la Biblia como unidad psicosomática. Pero ¿de qué está compuesto el hombre? Ni el alma ni el cuerpo dan razón de la imagen bíblica del hombre. La Biblia nos informa de que el hombre es una unidad e imagen de Dios, cualitativamente superior y no reducible a su entorno. La unidad nos dice no al dualismo, y la imagen de Dios nos dice no al monismo en sus versiones materialista (es más que el mundo que le rodea) y espiritualista (la imagen de Dios se predica del cuerpo humano también). El hombre ha sido creado por Dios (el mismo y único) y será salvado en su integridad psicosomática, no en una parte (el alma sola). En la economía de la salvación la encarnación, la Iglesia y los sacramentos son concreción corpórea de la autodonación de Dios. El hombre se atribuye a sí mismo un valor contable, y una dignidad y una libertad de valor incalculable; es distinto de la bestia, del vegetal y de las cosas. Con la patrística la reflexión de los misterios de la persona y de la obra de Cristo nos hacen percatar de que el hombre no es solo alma sino que también es cuerpo auténtico en su condición humana. Los primeros autores cristianos apologistas reivindicaron unánimemente la unidad del ser humano: Justino rechaza la naturaleza divina del alma de la doctrina platónica, pues el hombre existe entero imagen de Dios y creación suya; Taciano escribe que el alma no puede aparecer por sí sola sin el cuerpo, ni resucita la carne sin el alma; Ireneo dice que el hombre como imagen de Dios ha de ser referencia de una realidad visible que es el Verbo encarnado, pues de otro modo no podría ser imagen; Tertuliano escribe que al modelar el barro Dios pensaba en Cristo y que la carne es el quicio de la salvación, que nutrida con el cuerpo y la sangre de Cristo el alma se sacia de Dios, y la imagen de Dios por autonomasia es el Verbo hecho carne. Con los filohelenistas Clemente y Orígenes (siglo III) y con Lactancio y San Agustín (siglo IV) pone en el alma racional la esencia de la imagen divina, localizada en la parte superior del ser humano, el noûs. No hay en Clemente un valor peyorativo del cuerpo, que es morada del Espíritu. Tampoco en Orígenes hay una condena del cuerpo, pero con ellos hay una línea de pensamiento que no ven el cuerpo y la carne como la Biblia y la patrística. Lactancio defiende el origen celeste del alma y el origen terreno del cuerpo. San Agustín piensa que la parte mejor del hombre es el alma, pues el cuerpo no es todo el hombre sino su parte inferior; rechaza la doctrina platónica de la preexistencia de las almas, e integra el cuerpo en la verdad del hombre, pues cuerpo y alma unidos es donde hay hombre, una maravilla incomprensible al hombre; para San Agustín el hombre no consiste en la mente ni en la carne, sino que de la unión de espíritu y cuerpo es el hombre. El magisterio eclesiástico contempla la antropología como cristología o como repulsa de errores dualistas: Cristo es el hombre perfecto 
dotado de alma racional y cuerpo, pero no detalla la unión que se da entre estos y que será materia de la teología y el magisterio medievales. El primer concilio de Braga anatematiza a los que piensan que la carne no es creación de Dios, sino de ángeles malignos; un sínodo de Constantinopla condena algunas tesis de Orígenes de la preexistencia del alma y de la consiguiente encarnación como estado penal; un canon del IV concilio de Constantinopla estipula que el hombre tiene un alma racional e intelectual, y no dos como afirmara Focio. Durante los primeros siglos la antropología cristiana era cristología, pero con la escolástica medieval se percibe el horizonte de la escatología; de la unidad de alma y cuerpo del pensamiento patrístico se bifurca el pensamiento oscilando entre la tendencia filosomática de Ireneo y la filopsíquica de Agustín. Los teólogos medievales se movieron por el interés existencial de comprender al hombre en la historia salvífica y su desembocadura: la salvación tiene por beneficiario al hombre entero con cuerpo y alma, como la fe en la resurrección lo testifica. La antropología platónica ofrece un anclaje a la salvación del alma en detrimento del cuerpo, mientras que la antropología aristotélica no deja fuera de juego al cuerpo. Hugo de San Víctor introduce la corriente neoplatónica-agustiniana en la teología, diciendo que el alma es lo que Dios ha creado a su imagen y semejanza, y de aquí que sea inmortal; el cuerpo fue creado a imagen del animal y por esto su corruptibilidad, pero debido a su unión con el alma se le concede participar en la inmortalidad de ésta. Otros autores como Roberto de Melún y Honorio de Autún ven tan feliz y perfecta al alma separada que no ven para qué sirve la resurrección además de concordar con el símbolo de la fe. Gilberto de la Porrée dice que el hombre no es alma ni cuerpo, sino la unión de ambos, y así es persona; la resurrección no será del cuerpo sino del hombre. Para Guillermo de Auxerre la resurrección es necesaria para que el alma colme su tendencia natural al cuerpo. Roberto de Melun creía deber sostener que el alma es persona basándose en Lc 23,43 de la entrada de buen ladrón inmediata al paraíso. El platonismo ponía en cuestión la unidad sustancial que el hombre es, y el aristotelismo de la unidad sustancial cuestionaba la espiritualidad e inmortalidad del alma. Un ensayo de síntesis de ambas posiciones fue el de Pedro Lombardo que habla del apetito natural del alma hacia el cuerpo y de que el alma encarnada no es persona (sino el hombre entero). Avicena tuvo una posición ecléctica que admite la tesis del alma como forma del cuerpo por sus potencias y virtualidades, no por su esencia. El IV concilio de Letrán revalida contra el dualismo cátaro que el cuerpo pertenece a la naturaleza humana, pero sin indicar cómo entender esa unión almacuerpo. Santo Tomás de Aquino nos hace ver que las ideas filosóficas son útiles remodeladas en contacto con la fe: la realidad del alma se agota en comunicar su ser a la materia; el alma es una forma que posee y confiere sustancialidad. De aquí, la antropología tomista se sintetiza en: (a) El alma racional es forma por 
su propia esencia (no por sus potencias o virtualidades como dijo Avicena), y las funciones animadoras son su autorrealización. (b) El alma racional es la única forma en el hombre, el hombre no consta de alma y cuerpo sino de alma y materia prima. (c) El cuerpo es materia informada por el alma. (d) El alma no preexiste al cuerpo. (e) Alma y cuerpo no son sustancias que existen en acto por separado, sino sustancialmente unidas, el alma humana comunica su ser al cuerpo en el que subsiste. (f) El alma no es el hombre ni es persona. (g) Es más perfecto el estado del alma unido a su cuerpo que fuera del cuerpo, dándose la realidad unida hombre. Subsiste por tanto una dualidad en el plano metafísico de los principios del ser: alma-forma y materia prima. La motivación de la antropología de Santo Tomás era teológica. Tomás concentra en el alma racional lo que Aristóteles repartía entre psyché y noûs. Frente al modelo de Santo Tomás se objetó que el cadáver de Cristo no podía considerarse su cuerpo y que la veneración de reliquias quedaba sin apoyatura ontológica. Tras Tomás la teología sigue un plurimorfismo: el hombre consiste en la unidad alma-cuerpo y el alma se une sustancialmente al cuerpo. Pedro Juan de Olivi ataca la unidad de forma de la doctrina tomista, diciendo que en el hombre hay dos sustancias, alma y cuerpo, cada una con su materia y forma. Ricardo de Mediavilla dijo que las formas inferiores se ordenan a la superior (intelecto) que es forma plena; alma y cuerpo son sustancias incompletas; refuta que el alma sea la persona, algo que se remonta a Hugo Victorino, reservando la persona al compuesto alma-cuerpo. Escoto simplifica el esquema pluralista de la que surge la humanidad como entidad positiva que no es cuerpo ni alma sino la conjunción en la distinción de ambos. Estas explicaciones se diferencian de la tomista en la dificultad de comprender al hombre como ser uno, pues de dos o más sustancias no puede ocurrir otra cosa que una unión accidental. Cerca del siglo XIV se trata de rehabilitar la tesis tomista, así Knapwell habla de la imposibilidad de la unidad a partir de dos entes en acto y propone la tesis de alma-forma única deduciendo que cuerpo y alma no son realidades diversas, el cuerpo no existe sin alma y el alma hace uno con el cuerpo como la materia prima con la forma hace uno. Para Juan de París el cuerpo no es tal sin el alma y, por tanto es inexacto hablar de "alma y cuerpo" pues ella accede no a un cuerpo sino a una materia prima. El IV concilio de Letrán había afirmado contra el dualismo que el hombre se constituye por el alma y el cuerpo, y Vienne asevera que ambos elementos se unen sustancialmente, en concreto "el alma es verdaderamente por sí y en esencia la forma del cuerpo humano"; según el concilio la relación alma-cuerpo es esencial y la unidad del ser humano es sustancial, lo demás está al margen de la antropología cristiana. Unidad psicofísica, anímico-corpórea, según la Biblia. Vienne usa del esquema hilemórfico entonces ampliamente aceptado, lo que no significa que canonice el hilemorfismo. Es evidente que la intención de Vienne encuentra su 
mejor formulación en la concepción de Santo Tomás, y no en las teorías plurimorfistas (Olivi, Escoto, etc.). Se trata de una manifestación del sensus fidei y que ha de considerarse vinculante. Vaticano II recoge de la antropología bíblica el carácter unitario del hombre y su superioridad sobre los demás seres del mundo; por su inteligencia participa de la luz de la mente divina y reconoce que su alma inmortal y espiritual toca el fondo de su verdad. Describe al hombre en referencia a Dios (interioridad) y al mundo (condición corporal inserta en él); subraya la dimensión espiritual, dato accesible en la experiencia del hombre en sí mismo. Los materialismos del siglo XIX hacen que la antropología que había sido psicología, devino a la ciencia de la conciencia (Freud) y después a la ciencia de la conducta: al reino aristocrático del alma y del espíritu le sucede la presidencia democrática del cuerpo o de la materia. Los materialistas Feigl y Bunge se preguntan ¿qué es el alma?, el problema mente-cuerpo se discute filosóficamente. El filósofo Popper propone el dualismo interaccionista, al que se suman neurólogos como Eccles, Penfield y otros. La cuestión alma-cuerpo sigue en el tapete: ¿existe la mente? Y en caso afirmativo ¿es algo distinto del cerebro? La primera pregunta recibe respuesta afirmativa casi unánime, mientras que la segunda cuestión ¿se identifica la autoconciencia, la mente, con una entidad biológica o fisioquímica? Feigl crea la teoría de la identidad mente-cerebro, y manteniendo serias reservas su creador, Popper piensa que es una de las más influyentes desde una ontología materialista. Feigl trató de superar el conductismo reivindicando la realidad de la mente; hay factores causales de esa conducta: eventos, procesos y estados mentales poseen una realidad propia previa al comportamiento y causante del mismo. La mente es una realidad objetiva, pero no es la conducta, sino el principio interno de esa conducta. Feigl responde que la mente existe, pero es el cerebro. Según Feigl la neurología responsabiliza al cerebro de todo lo que es capaz el hombre. Para él experimentamos lo físico y lo psíquico de manera diversa, lo psíquico es percibido por medio del conocimiento autoconsciente, lo físico como objeto distinto de la propia autoconsciencia. La ontología que sustenta la teoría de la identidad es materialista fisicalista: lo psíquico es reducible a lo biológico, y lo biológico es reducible a lo físico; las leyes básicas del universo son exclusivamente físicas para ella, una realidad homogeneizada sin desniveles ni saltos cualitativos, ni rupturas entre ser y ser, con una continuidad entre el átomo de hidrógeno al hombre. El materialismo emergentista piensa que esta representación no es real: cada nivel supone el anterior, pero lo supera ontológicamente y es irreducible a él. El emergentismo argumenta ante el fisicalismo el hecho de la evolución: emergen nuevos entes que poseen propiedades que no han existido antes. Para el emergentista Mario Bunge el sistema nervioso central del hombre es un biosistema que supera el nivel fisicoquímico y el de la biología: el cerebro humano es emergente del área misma 
de la biosfera, y todo estado mental es un estado cerebral, pero no al contrario, "la mente es una colección de actividades del cerebro". El dualismo interaccionista presenta que hay entidades reales que son incorpóreas. En el área de las ciencias cibernéticas y los ordenadores hay intentos de homologar los organismos vivos y las máquinas especialmente desde la irrupción de la electrónica. Pero si una máquina puede ser considerada una entidad inteligente ¿por qué no considerar que los seres vivos son como máquinas? La lógica fisicalista aspiraba a esta formulación hombre = máquina. Pero es una reducción de todo lo real a lo físico y el hombre sería un objeto material con solo propiedades físicas. Mackay llegó a decir que toda conducta humana tendrá una explicación mecánica, y el cibernético Ruiz de Gopegui dijo que el emergentismo materialista le parece una versión moderna y pagana del viejo dualismo. Sentado el postulado fisicalista, procede a la doble homologación mente-cerebro y cerebro-máquina. Pero las investigaciones neurofisiológicas de las últimas décadas demuestran que estas hipótesis son inaceptables y no queda para ellos otra posibilidad que admitir que es un proceso material de elaboración de información, procesos físicos como los de inteligencia artificial de la máquina. Ruiz de Gopegui termina diciendo que somos autómatas conscientes, para concluir su interpretación maquinista del ser humano. Para él la autoconciencia no es privilegio del hombre pronosticando que pronto las máquinas lo podrán tener, sabrán lo que quieren hacer y por qué. La inteligencia artificial ya está equipada de memoria y de capacidad de razonamiento. Para él la mente es cerebro y el cerebro un robot, pasando del hombre-sujeto a la máquina-sujeto. Otros pensadores como Armstrong, Mackay y Turing lo habían anticipado, que la ciencia demostrará mañana lo que profetiza hoy. Ante esto Eccles, Penfield y Sperry recusan la identidad mente-cerebro y es falso que la neurología actual demuestre tal identidad como afirman Armstrong y Ruiz de Gopegui; no es un valor consolidado esta identidad cerebromáquina; y quedan puntos oscuros como no ocultan Ruiz de Gopegui, Feigl y Armstrong para dilucidar su teoría. Del monismo fisicalista pasamos al dualismo interaccionista con Popper, que en principio se asemeja al emergentismo, pero el hombre del dualismo parece el robot del fisicalismo. Tiene la ventaja frente al fisicalismo de que reconoce diferencias cualitativas entre los seres mundanos y permite una lectura humanista del mundo real: el hombre difiere de su entorno, es irreductible y superior ontológicamente. Considerar material lo que diverge cualitativamente del resto de la materia hace inferir que la mente no es una realidad física, química, biológica, material aunque no se dé sino en lo material, biológico y somático. Hasta Letrán IV la naturaleza humana consta de alma y cuerpo; Vienne enseña que alma y cuerpo se unen sustancialmente, pero el sujeto es todavía el alma; Vaticano II asevera que el hombre es uno en cuerpo y alma. Carne animada o alma encarnada. Hay actos preponderantemente 
corporales o espirituales, pero no puros del cuerpo o del alma. Hablamos de alma como coprincipio de la realidad humana cuya razón de ser es la encarnación. Hablamos de cuerpo como una porción de materia animada o espiritualizada. La unidad materia-espíritu se verifica en el hombre, el cuerpo es su manera de ser del espíritu humano. El hombre entero es a la vez alma y cuerpo, no como contigüidad de facto como pensaban los cartesianistas. La doble tentación denunciada por Pascal entre el angelismo y el animalismo monistas, ninguna hace justicia a la complejidad del ser humano, y en esto coinciden autores como Sartre o Merleau-Ponty. El cristianismo no niega ningún sector de la realidad, ni censura previamente al espíritu o a la materia, sino que trata de abarcar a ambos en síntesis coherente. El hombre es el interlocutor del diálogo entre creador y criatura, y anticipa la síntesis última que habrá entre creador y criatura en Cristo. El dualismo subsiste en expresiones como "la mente es el software y el cerebro es el hardware" o "el cuerpo es materia organizada". El hombre es todo entero, al mismo tiempo alma y cuerpo aunque éstos no son idénticos entre sí. El hombre es cuerpo en el mundo, el quicio del mundo, inmerso en el tiempo, de condición itinerante, al final del tiempo alcanza su propia identidad, su muerte es el fin del hombre entero, es un ser sexuado biológica, biográfica, social e históricamente. Vive en comunidad dialógica, comunicándose a sí mismo, la mujer no es subordinada al varón, su rostro revela su intimidad, el cuerpo no puede ser infravalorado, ni inferior o sospechoso; tampoco debería reducirse o resacralizarse por la glorificación neopagana de la belleza utilizable. La resurrección del cuerpo es lo más fiel a éste y antídoto a su depreciación. El hombre es alma, una expresión insustituible en teología pues tutela una serie de mínimos antropológicos innegociables para la fe cristiana. Significa su singularidad del ser humano y su apertura constitutiva a Dios, el hombre vale más que cualquier otra cosa del mundo, es más que lo mundano, es imagen de Dios. El quid del alma para la fe cristiana es teologal, es la capacidad de referencia del hombre a la verdad, al amor eterno, conocer de Dios su destino. El alma es coprincipio espiritual del hombre uno. Alma es el momento óntico transmaterial (irreductible a lo físico, químico o biológico) de la realidad humana que funda su valor y su capacidad teologal. El alma trasciende el mundo, endémicamente insatisfecho, cuerpo en el mundo y espíritu frente al mundo. Trascendente respecto del tiempo, se sabe temporal, se desea eterno. La fe cristiana espera una victoria sobre la muerte y le responde no con inmortalidad sino con resurrección. En una antropología dualista el alma se separa del cuerpo con la muerte, pero en una antropología unitaria la muerte es el fin del hombre entero. La esperanza del cristiano está en su resurrección. La antropología cristiana no es completa y conclusa, sino que profesa unos mínimos antropológicos. El alma y el cuerpo son dos factores de la realidad del hombre como criatura. Tomás de Aquino entendía por cuerpo el 
efecto de la actividad informante del alma sobre la materia. Otros autores han hablado con diferentes puntos de vista sobre alma-cuerpo. Zubiri indica que no hay unión sino unidad sistemática alma-cuerpo, una teoría rigurosamente metafísica que cubre con holgura los mínimos antropológicos de la fe cristiana. La Biblia no conoce la tesis de la muerte total. Letrán V define la inmortalidad del alma, para atajar el error de Pietro Pomponazzi que negaba la victoria sobre la muerte de la persona singular concreta, como alma forma del cuerpo del mismo sujeto. La doctrina de la inmortalidad del alma no se opone a la resurrección, hay que hablar de inmortalidad para poder hablar de resurrección y solo en la medida en que sea necesario para este fin. Esta inmortalidad no enseña que sea natural, puede ser gracia y no cualidad inmanente, que hace posible la resurrección del mismo e idéntico ser personal.

El capítulo cuarto se dedica a la dignidad de la imagen y el hombre como ser personal. El hombre es una naturaleza psicoorgánica y unidad sustancial de materia y espíritu. El hombre no solo es algo sino también alguien, tiene una naturaleza y es persona o sujeto que dispone de su naturaleza. Su ser-alma apunta a la trascendencia de lo humano sobre lo mundano; tiene una dignidad irreductible a lo infrahumano que corresponde a ser imagen de Dios. Por ser persona es libre y social. El origen del concepto de persona está en la experiencia religiosa, en el encuentro con Dios. De la inviolable majestad divina se sigue la participada dignidad personal del ser humano. Persona no es un término bíblico; pero describe la dependencia frente a Dios, la superioridad ante el mundo, y la igualdad ante el hermano; tiene por tanto mucho de relacionalidad. El pensamiento griego no conoció el concepto de persona; parece haber surgido del latín personare, resonar, por recoger la función amplificadora de la voz de actores y actrices. La naturaleza divina se realiza en tres personas o sujetos distintos que sigue siendo única: Padre, Hijo y Espíritu; los constituye sujetos su relación. Dios se realiza en cuanto se da: el Padre se da en el Hijo, y el Espíritu es dado por el Padre y el Hijo. La persona consiste en la relación, de la persona misma. El diálogo intradivino se prolonga en la creación y culmina en la producción de un ser imagen de Dios, capaz de escuchar, responder y donarse. La patrística afirma el valor y la dignidad del hombre sin comparación. En Calcedonia se designa a la persona (prósopon) en contraposición a naturaleza (hipóstasis). En la teología medieval, Boecio fue el primero que trató de definir la persona humana, y Justiniano la describe como ente jurídico más que ontológico, distinguiéndola de las cosas y del esclavo pues solo el hombre libre es ser personal. Tomás de Aquino usa en su definición la noción de subsistencia, o realidad que existe en y por sí, y no en otra: persona es lo más perfecto de toda la naturaleza, el ser subsistente en una naturaleza racional. Este concepto no alude a la relación 
como constitutiva de la persona humana. En Dios las relaciones son subsistentes, y Tomás afirma que las personas divinas son las relaciones subsistentes. Persona significa que no puedo ser poseído por otra instancia, me pertenezco a mí. La concepción solipsista del hombre es un sujeto clausurado en su propia suficiencia. Descartes ve al hombre relacionado consigo mismo y solo consigo mismo. Esta reducción del yo conduce en Hume a ver la conciencia humana como simple haz o colección de percepciones. El idealismo romántico sacrifica el yo singular al Espíritu absoluto objetivo, y el marxismo sumergirá la subjetividad de la persona concreta en el anonimato impersonal colectivo de la sociedad. Husserl recupera la relación interhumana de un sujeto frente a objetos y de yo frente al tú. Scheler da un paso más con su personalismo ético diciendo que el valor de la persona humana es superior a todos los valores de cosas, organizaciones y comunidades. La persona se vive a sí misma como responsable de sus actos. Ebner y Buber asignan a Feuerbach el mérito de descubrir la fecundidad de la relación yo-tú. Es ante el tú como el ser humano descubre al propio yo personal, conduciendo a descubrir el nosotros: estar dos en recíproca presencia es la única respuesta a ¿qué es el hombre? Lo que hace al hombre un ser personal es responder a Dios de modo que éste se comunique y se glorifique. Todavía está por hacerse una teoría verdadera completa de la persona. La relación no se circunscribe a lo racional del hombre, también el cuerpo es mediador de todo encuentro. En el hombre la realidad personal abarca la naturaleza pero se especifica por la relación. Subsistencia (disposición de sí) y relación se necesitan y complementan. El existencialismo del siglo XX afirma al sujeto participativo, dialogante comunicativo y disponible en fidelidad (Marcel); Jaspers no está lejos de su pensamiento. Heidegger y Sartre priman el existente concreto sobre todos los demás entes, por la subjetividad: el hombre existencial es el creador de la nada a partir del ser. El estructuralismo proclama la muerte del hombre no refutando el existencialismo sino por medio de nociones inocentes como saber, verdad y ciencia: solo hay un tipo de saber y de verdad, el de las ciencias experimentales o de la naturaleza. Al reduccionismo epistemológico se suma el reduccionismo ontológico: solo hay una realidad, las que manejan las ciencias de la naturaleza. No hay ciencias humanas porque no hay hombre; no hay historia porque no hay sujeto de la historia. Es el propio hombre el que pilota su propia autodisolución. El desnivel entre lo personal y lo natural es a lo que se ha llegado como estaba la filosofía griega ante la antropología cristiana. La moda estructuralista resultó más efímera que la existencialista, duró solo el decenio de los 70 . Autores cristianos como Garaudy dijeron que no hay nada más íntimo y esencial en cada ser humano que la presencia y el amor de otros. A fines de los años 80 el existencialismo, el estructuralismo y el marxismo humanista son hechos de crónica. La psicología conductista explicaba el yo como recurso para representar respuestas 
de modo unificado. La antropología cibernética, el reduccionismo biologista y otros drásticos regateos a la baja en la cotización de lo humano hace que tengamos que recordar puntos innegociables para el creyente, en concreto la realidad de persona. Su reflexión se basa en el misterio de la Trinidad divina, de donde deriva la dignidad personal humana, ser relacional (Dios, mundo, tú humano). En el AT Dios es el tú y el yo se afirma abrazando el tú o rechazándolo dialogalmente. El juicio bíblico sobre el ateísmo es como fenómeno de gentes insensatas y voluntades pervertidas. Solo el ser personal divino por excelencia puede conferir personalidad a su criatura, el hombre. El hombre es el tú de Dios y hay un ser humano, Cristo, que irradia la gloria de Dios. De ser el tú de Dios deriva la dignidad del ser humano. El hombre es ser supremo para el hombre y para Dios. El hombre es un fin (no un medio) para otro fin, Dios. El absoluto de Dios hace del hombre un absoluto relativo, porque Dios toma al hombre absolutamente en serio, y es la raíz de su inviolable dignidad y valor. El precio de cualquier ser humano es la vida de Dios encarnado (1 Co 6,20; 7,23; $1 \mathrm{Tm} 2,5-6$ ). Los pequeños son el sacramento de Cristo, signo eficaz de su presencia real en lo humano, como Cristo es el sacramento y la imagen de Dios. El que es incapaz de amistad es incapaz de religión (Marcel), pues el cristianismo consiste en hacer del otro semejante un prójimo y del prójimo un hermano. Y Cristo es el único mediador entre Dios y los hombres. El estatuto de personalidad es previo a nuestro encuentro, lo hace posible el encuentro interpersonal. Yo soy de Dios, no de mí, por eso debo ser para los demás. El hombre merece el mismo respeto sacro que merece Dios porque éste ha querido ser hombre. La antropología teológica se encuentra con la cristología. En la relación a Dios se halla la dignidad más absoluta del ser humano. El orden social debe subordinarse al bien de la persona. La verdadera libertad es signo de la imagen divina en el hombre (GS 17). La libertad no es solo facultad electiva (libre albedrío), sino que significa que puedo llegar a ser lo que soy, me presta la capacidad de ser mi identidad y elegir el bien (no como objeto sino como sujeto cuyo ser le es propuesto como tarea responsable). Ser persona significa disponer de sí y hacerse disponible. La libertad humana es interpelada, responsable, es un posicionamiento ante Dios. Jesús fue hombre soberanamente libre sin pecar. Dios no se impone a la libertad humana, solo puede convencerla por amor; su omnipotencia se muestra en crear a un ser capaz de negar a su creador. Todo acto libre tiende a su definitividad, a llevarlo a su término con compromiso y fidelidad (militante, activo, solidario). No hay libertad cabal sin todas las libertades, ni libertad personal sin libertad social; la libertad se vigoriza cuando el hombre trabaja en servicio a la comunidad. Para Skinner no existe la libertad; además de psicólogo dice que la tecnología debe desembocar en una ingeniería social. Para Wilson la libertad es solo un autoengaño. Ruiz de Gopegui dice que lo psíquico está regido por leyes de la naturaleza 
y no requiere libre albedrío, la libertad es una ilusión. Estos tres autores hurtan al hombre su condición de sujeto nivelándolo con la física o la biología; negando la subjetividad se niega la libertad individual y social, pues sin libertad responsable se destruye el sujeto o la persona, y anula su búsqueda de sentido y la noción ética-teológica de culpa, dando lugar a la ley del más fuerte sin sujetos ni fines sociales. La fe cristiana entiende la libertad como la respuesta a la conversión que Jesús propone, mediante la Alianza y la gracia, pues nos ofrece el perdón y la autodecisión. La acogida de la palabra evangélica para ser libres. La libertad cristiana comprende religación (como padre e hijo, o entre amigos, liberándonos), filiación adoptiva (contra toda esclavitud, la verdad nos hará libres, en fraternidad común) y servicio a los hermanos con amor (entrega hecha con humildad para liberarnos). La persona humana es un ser relacional, abierto al diálogo con un tú humano, imagen de Dios, de ahí su carácter social con una herencia genética (biológica) y cultural (histórica); ésta influye más que la anterior en la personalidad, como es la educación. La socialidad humana no es solo receptiva sino oblativa también, dando en su comunidad. La persona se logra como tal en la comunidad interpersonal, la sociedad es mediadora de la personalidad para que la persona se dé en acto, y el hombre es capaz de modelar la sociedad por la que ha sido modelado. La Biblia describe a Adán incompleto sin Eva, su unión conforma la célula de la sociedad, la familia. Las consignas que Dios da al hombre (creced, multiplicaos, llenad la tierra, sometedla...) no se consiguen con el individuo aislado. Dios elige a su pueblo, no individuos aislados. Las promesas a Abrahán o David las hace como personas corporativas (mencionando su descendencia). Los profetas exaltan la responsabilidad personal y mantienen la salvación comunitaria. El nuevo Israel, la Iglesia, el Cuerpo de Cristo, insertados por el bautismo nos hace beneficiarios del don salvífico de la vida nueva del Jesús resucitado. El hombre y Dios son seres comunitarios. La salvación no se da a individuos aisladamente. El pecado actúa como factor de desintegración que niega la relación con Dios y con su imagen. La gracia reestablece la comunión con Dios e interpersonal. Vaticano II dice que el hombre es un ser social que no puede vivir ni desplegar sus cualidades sin relación con otros. La vida comunitaria se proyecta hacia la nueva comunidad de hermanos en Cristo, que se consumará en la familia escatológica. Dios quiere a la humanidad como una familia de origen (creados) y destino (llamados). El principio, sujeto y fin de las instituciones sociales es la persona, el orden real debe someterse al orden de la persona. El creyente debe superar la lógica individualista en favor del bien común. Dios elige a los hombres no como individuos sino como miembros de su comunidad. El personalismo se hace en la comunidad, personalizando a los demás. La persona es relación y el ser personal es ser social para poder realizar su personalidad. El hombre encuentra su plenitud en su entrega 
sincera a los demás (GS 24,3). La fraternidad se logra con el dogma de la comunión de los santos. La Iglesia es espacio donde se vive lo que la fe proclama, signo sacramental de fraternidad escatológica, que espera y obra como significa. La Iglesia es creíble por el grado de transparencia para el amor fraterno de sus miembros.

El capítulo quinto se dedica a la actividad humana en el mundo y el hombre como ser creativo. Hemos visto la relación personal (con Dios, de inferioridad) y la social (con su imagen, de igualdad) del hombre; queda ahora ver la tercera relación (con el mundo, de superioridad). Ser en el mundo es más que estar, el hombre es un ser creativo, con presencia dinámica y activa: trabajo, progreso, ciencia, técnica, arte, cultura, praxis, política, etc. El hombre hace productiva su actividad y la tutela. El trabajo humano es encargo divino y afinidad del hombre y la tierra. El pecado degrada las relaciones armónicas hombre-medio, deja afectado penalmente su actividad que ya no es un paraíso como Dios había previsto; pero Dios no condena el trabajo sino al trabajador que ha pecado, desequilibrando su interior, el mundo que le rodea y su actividad. Tampoco hay una condena divina de la técnica, sino que surge un hombre dominado por las cosas que él debía dominar. Dios confiere al principio el dominio del hombre sobre la tierra y los animales; solo teniendo dominio se puede llenar la tierra, que es signo de señorío regio. El rey israelita es garante del orden social y cósmico, custodio del derecho, y garante del derecho de los débiles (huérfanos, viudas). El dominio regio tiende a la liberación de los seres, no a sojuzgarlos, promoción de la paz universal, concordia armónica, bienestar gozoso, y a prolongación de la bendición divina. El hombre es señor, con dominio vicario no propio, de la creación. Dios reclama en la Biblia que es el único señor del universo, y la tierra de los israelitas es propiedad del Señor. Dios ha puesto los cimientos de un edificio que su terminación corresponde a su imagen, el hombre concreador del mundo. Actividad y descanso son complementarios en el hombre, con la liberación del descanso sabático y un trabajo que no es esclavitud sino libre disposición del tiempo, una actividad generosa y creativa como Dios desplegó en su obra. El trabajo es para el descanso, que impide la degradación humana al nivel de máquina productiva, un medio (actividad) para un fin (consumación salvífica). La paz de Dios reestablece el equilibrio ecológico y la convivencia entre animales entre sí y el ser humano. La pereza y la holganza se condenan en los libros sapienciales. Cristo está en el comienzo, en el centro y en el final de la realidad; la gracia de Cristo tocará el mundo y con la mediación humana Dios será todo en todas las cosas. Progreso y gracia, sin identificarlas, forman parte de la historia y apuntan al mismo fin único. Calcedonia nos habla de las dos naturalezas del Verbo encarnado. Dos tesis defendidas por Gaudium et Spes (Vaticano II) 
sobre la actividad humana son: (a) La bondad radical de la materia y del tiempo (con la consiguiente valoración positiva del "progreso" como perfeccionamiento en el tiempo de las realidades materiales y del orden del mundo). (b) La doctrina de la gloria de Dios como fin de lo creado (abundando en lo dicho en Vaticano I) y participación de la bondad divina. Por ello la actividad del hombre no debe valorarse solo desde la categoría moral subjetiva de la buena intención, sino por el valor ontológico objetivo de hacer con ella la voluntad de Dios sin depender solo de ese propósito. La tradición y la mejor teología han permanecido fieles al doble principio enunciado. La revelación y la competencia de todos pueden esclarecer el camino emprendido por la humanidad. La actividad humana responde al propósito divino; cualquier actividad como el trabajo femenino en la familia confirma el valor objetivo y no solo subjetivo de la actividad humana. La acción humana coopera a la acción divina creadora como su prolongación pues es creación del mundo. Tareas modestas u oscuras o cualquier trabajo en servicio a los hermanos contribuyen a este fin. Las victorias humanas son signo de la grandeza divina. La actividad humana procede del hombre y se ordena al hombre. El trabajo perfecciona la obra y al operador. La autorrealización humana es prioritaria sobre el mero acumular riquezas exteriores, pues el hombre vale más por lo que es que por lo que tiene (Marcel). El fin último de la actividad humana es la persona. Sacrificar el hombre concreto para el progreso técnico o la liberación del hombre genérico es lo que ocurre en el capitalismo y en el socialismo marxista, que atentan contra la esencia de la actividad humana y su sentido. La autonomía temporal (las cosas creadas y la sociedad tienen sus propias leyes y valores) es reconocida en la cultura y en las ciencias sin desvanecer la criatura sin el Creador; y la teoría de la doble verdad no es admisible en la conciencia cristiana pues lo profano y la fe tienen por origen el mismo Dios. El mundo secularizado no tiene carácter sacro. El pecado distorsiona el progreso subvirtiendo la jerarquía de valores. El progreso puede contribuir a la felicidad humana o transformarse en instrumento de pecado. El mandato nuevo del amor al modo gratuito como lo da el Padre construye la praxis cristiana. El verdadero progreso es efecto de la gracia, no hay dos historias (la profana y la sagrada) ni dos fines (el natural y el sobrenatural): el Espíritu de Cristo conduce la historia a su fin único. Los buenos frutos de la naturaleza y de nuestro trabajo los encontraremos limpios de toda mancha, transfigurados e iluminados, consumados en la nueva creación. Los avances éticos de justicia y fraternidad mayores valen más que los progresos técnicos. La amenaza nuclear se menciona en GS y no la crisis ecológica. La tesis conciliar es de primado del hombre sobre el trabajo y la prioridad de su aspecto subjetivo sobre el objetivo, pues justicia y solidaridad deben ser componentes de una nueva teología del trabajo. Según la fe cristiana el hombre creado como homo faber cumple su vocación de imagen de Dios. Las 
dimensiones de la acción humana son la natural-biológica (el hombre es un ser carencial que se autocompleta siendo práxico, transformando los condicionamientos carenciales en oportunidades vitales por la praxis y la cultura), la personal (el trabajo es condición de posibilidad de realización personal como fin vocacional, además de medio de subsistencia por el salario; buscar tener y no ser frustra psicológicamente la personalidad, la aliena; la ciencia y la técnica son tan creativas como el arte), la social (el trabajo articula las relaciones hombrenaturaleza e individuo-sociedad; la acción del hombre repercute en su persona y en lo social, crea comunidad que coadyuva al bien de todos; más que un deber el trabajo es un derecho pues el paro desintegra la personalidad, por ello hay que reconvertir la cultura de los intereses en cultura de solidaridad que promocione personas, no las destruya, fusione hermanos) y la configuradora de lo real (el ser humano es más que mundo o naturaleza, el homo faber dirige y promueve la génesis de lo real a su consumación). Vaticano II admitió que la Iglesia y los cristianos no reconocieron en momentos críticos la autonomía de lo temporal. En los últimos siglos la fe en el progreso se presenta como reemplazo de la fe en la providencia, pero el conocimiento científico no tiene significado existencial para el hombre. La tecnología puede escapársele al hombre de las manos si no la controla eficazmente desde fuera ya que no tiene capacidad interna de autocontrol. Tomar como índice de progreso el aumento de los bienes de consumo es falaz. Progreso es el proceso de enriquecimiento armónico del hombre y de la naturaleza que facilite el desarrollo integral de todos los hombres (PP 14,42). El progreso es irrenunciable y solo será posible con la ética que devuelva su carácter humano y sus virtudes humanizadoras, asumiendo los valores superiores del amor (PP 20). El discurso cristiano sobre realidades terrenas tiene que extenderse a realidades sociopolíticas, pues la auténtica teología del progreso ha de desembocar en una teología de la praxis político-social que responda a la voluntad de Dios, con reformas sociales morales para el bien común. El recurso a la violencia utilizada como mal menor se basa en un recurso ante una situación injusta que no se puede cambiar por otros medios y que sea eficaz. No se puede oponer un veto al uso de la violencia armada desde la tradición moral cristiana. Según Nisbet el futuro de la idea de progreso depende del futuro de la religión. Pues en la raíz del progreso está el sentido de lo sagrado.

El capítulo sexto se dedica a la cuestión del origen y el hombre ser creado. Lógica y antropológicamente que el hombre sea creado por Dios es la primera afirmación de la biblia sobre él. Queda no obstante resolver el problema del origen del ser humano. La respuesta de la teología actual sobre su origen puede ser compatible con la perspectiva evolucionista, y ha habido un debate sobre el monogenismo-poligenismo y el pecado original. Con las obras de Charles 
Darwin el antropocentrismo queda más seriamente cuestionado por la teoría evolucionista que por la heliocentrista. Posteriormente algunos autores han tratado de conciliar y estudiar las condiciones de una alianza entre evolución y filosofía tomista. En 1860 un concilio provincial de Colonia declaró contrario a la Escritura y a la fe la tesis que asigna al cuerpo humano un origen animal transformado hacia más perfección. Era una declaración no vinculante por ser emitida por un órgano local y por no haber sido ratificado en algún concilio. En 1909 la Comisión Bíblica menciona la peculiar creación del hombre, la formación de la primera mujer desde el hombre y la unicidad del género humano, pues se consideraba doctrina segura, declarándose autorizada por la Comisión Bíblica en 1948. El peligro de que las tesis materialistas de no pocas versiones evolucionistas den al traste con la primacía ontológica y axiológica del hombre frente a otros seres, hizo que la doctrina de que el cuerpo de Adán fuera creado fuese católica. La oposición al evolucionismo fue más fuerte entre los escrituristas que entre los dogmáticos. En 1941 Pío XII dirige un discurso a la Pontificia Academia de las Ciencias que sostenía la diferencia esencial entre el animal y el hombre, prohíbe considerar padre de un hombre a un ser no humano y dijo que la ayuda recibida por el primer hombre, la mujer, viene también de Dios. El mismo pontífice en 1950 dijo en su encíclica Humani Generis que el magisterio de la Iglesia no se opone a la doctrina del evolucionismo, si se entiende el origen del cuerpo humano de materia ya existente y viva; la tesis evolucionista no es aplicable al origen del alma, y la fe católica obliga a creer que es creación inmediata de Dios; los cristianos tienen que acatar pronto el juicio de la Iglesia que es intérprete auténtico de la revelación. En la creación de cada ser humano la Biblia acontece como efecto de la acción de Dios que llamamos creación. El hombre es efecto de causalidad trascendente (creación) o de causalidad inmanente (evolución o generación); ambas respuestas eran compatibles en HG: el origen del cuerpo era de ciencia, el origen del alma era de fe. Pero la encíclica habla del origen del cuerpo o del alma y no del origen del hombre. La fe sostiene que el hombre es creación de Dios. Si María fuese madre del cuerpo de Jesús ¿cómo reconocer que es madre de Dios? Cuerpo y alma no existen por sí sino en y por el hombre. El actuar de Dios no es detectable fenomenológicamente, y sin embargo Dios actúa en el mundo como fundamento real y trascendente del proceso evolutivo en el mundo, desde la raíz de cada ser creado. Si hubiera evolución se diría que el mundo progresa ontológicamente a más: lo menos se autotrasciende por el impulso divino. Dios y los padres (o prehomínidos) son causa completa y no parcial del hombre. La causalidad de Dios la llamamos creación, y es trascendente; la causalidad de la criatura es generación u hominización, y es categorial. Cada hombre procede de un acto biológico generativo cuyo fin es la multiplicación de la especie, y su lógica tiende a la reproducción. Cada hombre es 
persona, nueva, singular e irrepetible; con valor absoluto y querido como fin; es más que hijo de sus padres y miembro de la especie, es creación inmediata de Dios con peculiaridad irreductible, interlocutor de un diálogo permanente; no se deriva de la nada. El alma es el coprincipio espiritual del ser personal humano (Pío XII), creada inmediatamente por Dios pone en la existencia una entidad nueva válida en sí misma, que tiene libertad. La teología haría bien en ser expectadora de eventuales contenciosos sobre la validez de las teorías evolucionistas. No podemos comprometer la credibilidad de la fe involucrándola en cosmovisiones cerradas y excluyentes. El concepto bíblico de creación va unido a un contenido histórico-salvífico y escatológico. Dios acompaña permanentemente en el devenir de lo real y consumará el proceso entero en la nueva creación. Admitir el evolucionismo supone admitir el poligenismo del origen de la humanidad, de múltiples parejas, lo que entra en una situación embarazosa para la doctrina del pecado original que era monogenista. HG se mostraba contraria al poligenismo y éste es doctrina vinculante por revelación y por el magisterio irreformable de la Iglesia. Para la teología hay hombre donde hay ser personal capaz de responsabilidad ética y apto para el diálogo histórico-salvífico con Dios. El papel bíblico de Adán no exige la paternidad biológica, como no la exige de Cristo; todos somos solidarios de Cristo y no descendemos de él. Abrahán es padre de todos los creyentes incluso de los que no proceden de él por la vía biológica. El canon tercero de Trento enseña la universalidad del pecado y de la redención de Cristo. HG y Pablo VI hablan del poligenismo como supuesto no demostrado, como HG lo había dicho del evolucionismo, pero tras un artículo de Flick la premisa poligenista se acepta en la teología católica aunque no signifique su canonización y que además es irrelevante para los creyentes. El reduccionismo biologista de lo humano pretende nivelar lo humano con lo animal, del "hombre procede del animal" (Darwin) a "el hombre solo es un animal" hay solo un paso. Entre el hombre y el mono hay común un patrimonio genético del 98\%. Dos líneas de investigación en la ecuación hombre-animal: la etología (analogías en el comportamiento animal y humano) y la genética (sobre los mecanismos genéticos que fundamentan esas analogías). Compartimos con los monos el 99,5\% de nuestra historia evolutiva y más del $95 \%$ de nuestro equipamiento genético, por lo que Wilson dijo que el antropocentrismo es un vicio intelectual gratuito y nocivo. La sociobiología puede apoyar a la etología en encontrar pruebas decisivas en favor de su tesis. Pero la inteligencia y la dimensión ética-religiosa para Wilson son mera biología. Para él el altruismo no es opción libre y meritoria sino pulsión genética; en resumen, los genes sostienen la cultura y la cultura es función genética. Biólogos, filósofos de la biología, etólogos, genetistas y teóricos de la evolución, filósofos, teólogos y psicólogos hablan del hombre como una originalidad estructural, funcional y ontológica 
que además de biológica es irreductible a la animalidad pura. El hombre tiene una peculiaridad excepcional, es inadaptado y mediocre en su biología pero sobrevive y domina sobre toda la realidad. Dónde puede llegar el animal, hasta dónde no puede llegar y lo que de ningún modo puede hacer son límites operativos fijados en su constitución y cualidades. La confección de útiles y la asimilación del lenguaje humano que sugiere la etología queda en evidencia al ver la ausencia de útiles secundarios (que sirven para fabricar otros útiles) o de útiles ociosos (que no sirven para necesidades biológicas), y que el lenguaje humano es único en el reino animal. Además el hombre posee conciencia reflexiva (autoconciencia) y capacidad simbólica; mientras el animal sabe, el hombre sabe que sabe y puede considerarse a sí mismo como objeto de propia reflexión. La reducción sociobiológica de la ética a la genética ha sido refutada por la confusión entre presupuestos y causas (los genes son presupuesto, pero otras instancias modelan las capacidades genéticas causando el comportamiento humano), por la mitificación de los genes que es gratuita y altamente inverosímil, por la magnificación de los comportamientos innatos sobre los adquiridos (que dependen más de la educación y la cultura que de la herencia biológica), por el abuso del argumento de analogía ("los animales están determinados genéticamente, luego el hombre también"; también se toma de la cultura lo que después se dice que tienen los animales, ignorando las diferencias como que las sociedades animales son rígidas y las relaciones individuales quedan invariadas), por el desprecio sistemático de la dimensión simbólica del hombre, único dotado de conciencia y reflexión, que procede de la cultura más que de la naturaleza, y por una explicación errónea de la ética (pues en los animales no hay ética según Ayala, quien ve en el "amor al prójimo como a uno mismo" la esencia del altruismo y que no es biología, por lo que la ética no tiene base evolutiva según Ruse). Por ello se percibe el crónico destino de las antropologías extrabíblicas entre el angelismo dualista y el animalismo biologista. Pero el hombre no es ángel degradado ni animal maximizado. Para la Biblia lo peculiar humano no es que el hombre esté por encima de los animales sino por debajo de su Creador divino. Lo cuantitativo no desvelará las cualidades del hombre como imagen y semejante a Dios.

El objetivo del autor del libro es exponer la antropología tanto cristiana como desde otros puntos de vista presentes en el mundo en un lenguaje asequible en general a un lector iniciado en teología y filosofía, recurriendo a una bibliografía tanto bíblica y magisterial, como de otros autores cristianos y no cristianos, contrastando ambos enfoques a las mismas cuestiones y bien organizado en dos partes y seis capítulos que desarrollan el contenido. 
Desde la fe el libro aporta la visión cristiana tanto del AT como del NT, de los siguientes complementos desde la Iglesia en su magisterio extraordinario y ordinario, así como de la visión de otros teólogos, exégetas, filósofos y científicos creyentes, así como de otras confesiones cristianas.

La originalidad de la obra es su recapitulación del estado de la cuestión actualizada a la fecha de su publicación, año 1988. Destaca la visión bíblica y eclesial, así como las controversias surgidas en el mundo sobre la antropología tanto a nivel interno de la Iglesia como entre otras posiciones no católicas. En concreto se da un espacio a la visión evolucionista del hombre que no ha sido probada y que no afecta en esencia a la tradición y magisterio de la Iglesia, que se ha mostrado abierta a las aportaciones de estas teorías relativamente recientes.

Resultan algo difíciles de entender las posiciones o críticas del autor sobre algunos otros autores que entiendo que merecen respeto aunque se evidencien las limitaciones de algunas de sus teorías que en muchos casos no merecerían respeto.

Desde el punto de vista pastoral entiendo que se aportan elementos claves de la antropología teológica que pueden ser expuestos en la predicación como complemento a la palabra de Dios, por ejemplo algunas conclusiones de la Iglesia en encíclicas que han tratado estos aspectos. El valor pedagógico es alto, pues recuerda la verdadera condición del hombre como inferior a Dios, igual a su prójimo, y superior al resto del mundo.

Desde mi punto de vista personal encuentro agradable el contenido bíblico y más abrupto la aportación materialista a la cuestión por su parquedad y obsoletismo simplificador que pretenden explicar con pocas ideas algo que escapa a la capacidad humana actual como es su propio ser y el del hombre en su complejidad.

Un interrogante que me planteo es el cómo de la resurrección del hombre, que si bien tiene respuesta desde la fe y la revelación, escapa a los medios humanos actuales de observación o análisis excepto por el testimonio histórico y eclesial de la resurrección de Cristo y sus promesas para los hombres. 


\title{
REFERENCIA BIBLIOGRÁFICA
}

Ruiz de la Peña, Juan Luis. Imagen de Dios. Antropología Teológica Fundamental, Sexta edición. Maliaño: Sal Terrae, 1988.

\author{
Mariano Ruiz Espejo \\ Universidad Católica San Antonio de Murcia \\ Campus de los Jerónimos 135 \\ Murcia (España) \\ https://orcid.org/0000-0001-6648-4472
}

